\title{
Event Carnival sebagai Media Komunikasi Pemasaran: Studi Kasus di SMA PKP JIS
}

\author{
${ }^{1}$ Yayat Wahyat Herianto, ${ }^{2}$ Irwansyah \\ ${ }^{1}$ Fakultas Ilmu Komunikasi, Universitas Mercu Buana Jl. Meruya Selatan No. 1 Jakarta, 11650 \\ ${ }^{2}$ Fakultas Ilmu Sosial dan Ilmu Politik, Universitas Indonesia Depok 16424 \\ E-mail: ${ }^{1}$ yayatherianto.yh@gmail.com; ${ }^{2}$ dr.irwansyah.ma@gmail.com
}

\begin{abstract}
Abstrak: Penelitian ini bertujuan untuk mengenalkan sebuah event di lembaga pendidikan dengan mengadopsi event budaya yang marak di Indonesia seperti Jember Fashion Carnaval. Event yang diberi nama Carnival ini berdasarkan penelitian telah menunjukan hasil; (1) Event carnival dapat meningkatkan brand sekolah, (2) Kegiatan event Carnival yang diikuti oleh sekolah tingkat SMP dan SMA menunjukkan adanya pembentukan masyarakat jaringan, (3) event yang berbasis kearifan lokal dan budaya masih jarang dilakukan disekolah-sekolah, (4) event Carnival bagi SMA PKP JIS merupakan bagian dari komunikasi pemasaran yang penting dalam rangka promosi sekolah. Penelitian ini menggunakan desain kualitatif dengan pendekatan studi kasus. Data dilakukan melalui observasi, wawancara dan studi dokumentasi.
\end{abstract}

Kata Kunci: event, komunikasi pemasaran, carnival

\begin{abstract}
This study aims to introduce an event in educational institution by adopting cultural event that was rife in Indonesia such as Jember Fashion Carnaval. The event which was named Carnival based on research has shown results. (1) Event carnival can improve the school brand, (2) Event Carnival activities that were attended by many junior and senior high schools indicated the formation of a network society, (3) event which were based on local wisdom and culture was infrequently done in schools. (4) Carnival event for PKP JIS High School was part of marketing communication that was important in the context of school promotion. This study uses a qualitative design with a case study approach. The data is carried out through observations, interviews and documentation studies.
\end{abstract}

Keywords: event, marketing communication, carnival 


\section{PENDAHULUAN}

Event merupakan kegiatan penting dan menarik karena bentuknya yang berbeda serta polanya yang menawarkan aneka ragam aktivitas yang bisa dinikmati oleh banyak orang. Hasil riset menunjukkan bahwa event memberi nilai pengalaman yang berpengaruh secara positif dan signifikan pada kepuasan dan kepercayaan masyarakat $(\mathrm{Wu}$, 2016). Bagi (Brown \& James, 2011)this treatment requires large staff numbers. A mobile linear accelerator unit dedicated for electron beam intraoperative radiation therapy (IORT(Getz, Andersson, \& Carlsen, 2010)(Crowther, 2011) event merupakan bagian dari konsepsi atau gagasan secara sosial yang memiliki agenda dalam pemberian makna sebuah konsep bisnis yang berbeda, dengan para pengunjung atau komunitas yang berbeda serta desain event yang selalu berganti atau berubah.

Hakikatnya event merupakan program yang lahir secara alamiah yang memadukan komunikasi pemasaran yang dapat berpengaruh langsung pada konsumen (Wu, 2016). Dalam komunikasi pemasaran terdapat sebuah proses dan konsep dari produk dan jasa yang terintegrasi dengan konsumen melalui saluran saluran komunikasi (Chitty, 2008). Selain itu, festival dan event berkontribusi terhadap pendapatan ekonomi masyarakat lokal, meningkatkan perasaan gembira secara spiritual, hubungan dengan masyarakat dan ekonomi (Pan, Pan, \& Huan, 2013).

Kegiatan event merupakan bentuk transformasi ekonomi dan kultural tentang pentingnya memperingati dan merayakan sesuatu di dunia Secara berbeda. Dilihat sejarahnya, kegiatan event telah dilakukan sejak adanya revolusi industri di Inggris dengan adanya kegiatan pameran hasil industri. Dengan menggunakan nama exsibisi, kegiatan ini mendapatkan sukses besar karena dihadiri oleh pengunjung yang mencapai 6 juta orang atau $25 \%$ dari total populasi penduduk Inggris (Catwright, 1996). Tercatat dalam sejarah, kegiatan eksibisi internasional pertama ini berhasil memberi keuntungan finansial sebesar 180.000 (Noor, 2017).

Konsep Event didunia pendidikan secara umum merujuk pada pengertian yang diungkapkan oleh Rahma (2017). Menurut Rahma, event dapat berbentuk pameran, pertunjukan dan festival. Dalam arti yang lebih luas, event diartikan sebagai suatu kurun waktu kegiatan yang dilakukan oleh sebuah organisasi dengan mendatangkan orangorang kesuatu tempat agar mereka memperoleh informasi atau pengalaman penting. Dalam konteks ini event dapat dipahami sebagai media komunikasi pemasaran karena didalamnya terdapat kegiatan menginformasikan sesuatu dan memberi manfaat personal dan menjadi pengalaman penting bagi mereka yang mengikutinya.

Fenomena atau gejala munculnya event menjadi momentum dan titik penting pada abad ke 21 sebagai bentuk meningkatnya model pendekatan baru dan sistematis, termasuk dalam dunia akademis (Getz et al., 2010). Adanya event berakibat meningkatnya riset yang berfokus pada isu-isu yang terstruktur (Getz et al., 2010). Dunia pendidikan mendapatkan ruang yang lebih luas dalam mengembangkan dan mengkaji event sebagai sebuah model pembelajaran yang menarik.

Hasil refleksi dan evaluasi terhadap kegiatan event di Finlandia, menjadi inspirasilahirnyamodelpembelajaranbaru (Slaughter, 2013). Event dinilai memberi pengalaman dalam mempraktikan teori ke dalam aktivitas lapangan, karena para pelajar melakukan pengelolaan langsung kegiatan dan dibuktikan dengan portofolio (Slaughter, 2013). Menjadi temuan bahwa saat para pelajar menyiapkan event 
sesungguhnya mereka sedang belajar tentang manajemen, sosiologi, hubungan masyarakat, ekonomi, public speaking dan kewirausahaan.

Event merupakan sebuah pertemuan besar beragam kepentingan dan tujuan. (Kose, Argan, \& Argan, 2011) berpendapat bahwa event adalah bentuk kegiatan yang menyenangkan yang dilakukan secara bersama-sama untuk membuat dan menciptakan waktu yang berkualitas. Dari sisi ini terlihat bahwa filosofi awal dari munculnya event adalah membuat aktivitas yang menyenangkan, dan penghargaan terhadap arti waktu, yang bisa dimaknai sebagai pencarian identitas. Menurut (Cerulo, 1997) identitas dibangun dan diproduksi secara kultural serta dikonstruksi secara sosial dan terus-menerus dibentuk dalam interaksi.

Mencari identitas melalui proses interaksi dengan berbagai kelompok dan pemangku kepentingan dapat membangun reputasi sekolah. Sekolah dapat menampilkan sesuatu yang penting dan berbeda dan memiliki kesan mendalam terhadap kelompok masyarakat yang membutuhkannya. Tuntutan agar sekolah kreatif dan inovatif dalam menyusun program yang menarik sejalan dengan lahirnya kelompok milenial yang memiliki pandangan tersendiri. Dalam proses ini kreatifitas dan imajinasi yang dimiliki dapat dituangkan kedalam materi dan bentuk event. Yosal Iriantara (2007) berpendapat bahwa memimpin kehidupan pendidikan adalah mengembangkan dan menjaga konteks munculnya imajinasi. Seringnya event di sekolah bisa menjadi lahirnya imajinasi dan karya yang menarik.

Bagi sekolah, mengadakan event merupakan praktik seperti halnya perusahaan dijalankan. Sekolah dapat memperoleh banyak manfaat selain bentuk promosi melalui komunikasi pemasaran, juga upaya pembentukan citra atau reputasi lembaga. Reputasi yang terus diperbaiki dan dipertahankan akan menjadi identitas dan akan menciptakan an identity having contunity (identitas yang bertahan lama dan permanen) (Amri Yusuf, 2018).

Lembaga - lembaga pendidikan, termasuk universitas di dunia juga melakukan cara dalam membentuk brand. Melalui pengelolaan komunikasi universitas, Veronica Dal Buono dan Furlio mempublikasikan temuannya bahwa universitas yang ingin memiliki branding yang kuat harus memiliki target pasar yang khusus, mempunyai strategi pengembangan merk, membangun kesadaran merk, menumbuhkan kepercayaan dan menjamin adanya kegiatan yang sudah menjadi tradisi. Menurut Veronica dengan menunjukan konsep-konsep strategi branding dari A Aeker (1991) Brookrs (2000), Buffo (2002) mengemukakan sebuah pendekatan dalam membangun brand yang ada di masyarakat.

\section{METODE}

Metode penelitian ini menggunakan model analisis studi kasus yang dikembangkan oleh Burhan Bungin (2012). Tulisan ini menggunakan domain ganda, studi kasus yang dapat dihubungkan dengan fenomenafenomena lainnya. Dalam studi kasus ini terdapat dua domain yaitu event carnival dan komunikasi pemasaran. Merujuk pada pendapat Yin (2002) penelitian ini menggunakan tipologi studi kasus deskriptif yang harus menggunakan pertanyaan How (bagaimana) dan why (mengapa). Peneliti dalam melakukan pendalaman materi juga mewawancarai informan dan melakukan focus group discusion (FGD) untuk bisa mendapatkan gambaran utuh tentang event carnival. Konfirmasi data dilakukan melalui panitia, pengurus Osis dan mahasiswa program study event Universitas Prasetiya 
Mulya.

\section{TEMUAN DAN PEMBAHASAN}

Konsep event mengalami evolusi sejalan dengan perubahan dan perkembangan masyarakat. Faktorfaktor dominan yang mendukung adanya perubahan antara lain modernisasi pembangunan, cara berpikir, teknologi infomasi, dan perkembangan budaya masyarakat. Perubahan selera konsumen yang banyak dipengaruhi oleh kemajuan kebudayaan suatu bangsa juga ikut mempengaruhi konsep event.

Banyak istilah yang selama ini disamakan dengan event. Beberapa event memberi nama exhibition, festival, trade show, karnaval dan lain-lain. Secara umum isi dari kegiatan tersebut ruang lingkup aktivitasnya sama dengan event.

Menurut Rogers (1998), lahirnya konferensi di Inggris dimulai dengan munculnya kongres politik dan keagamaan, sementara di Amerika Serikat ditandai dengan adanya konvensi perdagangan dan asosiasi profesional pada akhir abad kesembilan belas. Lebih jauh, Shone (1998) mengungkapkan meskipun perkembangan yang besar di industri konferensi terjadi pada era tahun 1960an, tetapi perkembangan lainnya dimulai lebih dari 250 tahun lalu, meskipun tidak dapat dipungkiri bahwa events telah mengakar sejak lama dan perkembangannya dimulai dari kegiatan yang diselenggarakan ribuan tahun yang lalu.

Kegiatan event kini menjadi agenda prioritas dari masing masih pemerintah daerah. Beberapa event bahkan sudah menjadi destinasi wisata kelas dunia seperti Ubud writers and festival di Bali, Jember fashion carnival, Banyuwangi ethno carnival, Borobudur marathon dan lain lain. Dengan adanya keterlibatan yang besar dari suatu kegiatan yang berorientasi bisnis, budaya dan pendidikan, banyak pemerintah daerah saat ini memberikan kontribusinya berupa pemberian sponsor pada kegiatan festival dan sejenisnya. Lebih jauh, harapan pemerintah daerah agar event ini dapat mengangkat nama baik wilayahnya yang kemudian dapat meningkatkan taraf ekonomi masayarakat.

Ada lima jenis kategori event menurut Ary Noor ( 2017) :

(1) Special event juga meliputi semua aktivitas hidup manusia, special events merupakan kegiatan yang sangat besar dan kompleks. Special events dapat diselenggarakan mulai dari jenis event perorangan yang sederhana dan kecil seperti pesta ulang tahun atau pesta pernikahan sampai dengan events yang besar.

(2) Leisure event telah berkembang sejak bangsa Roma menyelenggarakan kegiatan gladiator. Bentuk leisure event yang ada saat itu adalah berupa pertandingan yang diselenggarakan di Coloseum, Roma, Italia, dengan susunan tempat duduk berupa teater dan menampilkan petarungpetarung pada pertandingan gladiator tersebut;

(3) Personal event merupakan kategori lain yang membentuk special event. Yang termasuk dalam personal event adalah segala bentuk kegiatan yang di dalamnya terlibat anggota keluarga atau teman. Banyak aspek kehidupan masa kini telah mengubah bentuk asli kegiatan personal event, misalnya pesta ulang tahun, pesta pernikahan bahkan termasuk juga perayaan-perayaan pribadi lainnya.

(4) Cultural event menjadi kategori yang membangun special event. Budaya selalu identik dengan upacara adat, dan tradisi memiliki nilai sosial yangtinggidalamtatananmasyarakat, sehingga penyelenggaraannya saat 
Yayat Wahyat Herianto, dkk. Event Carnival sebagai Media Komunikasi Pemasaran...

ini menjadi sangat penting. Terlebih lagi dengan adanya kemajuan teknologi, penyelenggaraan cultural event akan lebih menarik dan berkesan yang dapat disesuaikan dengan keadaan saat ini.

(5)

Organizational

event

merupakan kegiatan besar pada setiap organisasi. Pada kategori ini, bentuk event yang diselenggarakan tentunya disesuaikan dengan tujuan organisasi. Contohnya konferensi yang diselenggarakan oleh organisasi partai politik, bisa juga berupa eksibisi yang diselenggarakan oleh perusahaan, misalnya pameran telepon genggam atau berupa pameran dagang bagi perusahaan untuk memperkenalkan produk terbarunya.

Penelitan yang dilakukan $\mathrm{Wu}$ (2016) menjelaskan bahwa event marketing merupakan strategi yang penting termasuk dalam mengembangkan wisata regional. Event juga dapat membentuk image (citra) dan daya tarik yang kuat bagi masyarakat. Pelayanan menjadi simbol adanya hubungan yang berkelanjutan dan komitmen. Cara-cara ini dapat meningkatkan efek positif pada perusahaan. Wu mengungkapkan manfaat event sebagai aktivitas yang memiliki pengaruh/ dampak secara signifikan terhadap suatu peristiwa/pengalaman yang bernilai.

Dalam banyak event para pengunjung merasakan sesuatu yang bernilai setelah melihat isi kegiatannya yang sesuai dengan karakter dan kepribadiannya. Mereka sangat terinspirasi dan biasanya akan kembali datang pada saat event diadakan. Dari hasil wawancara dengan beberapa pelajar diperoleh informasi beberapa club band yang disukai pelajar. Di SMA PKP pelajar sangat menyukai event musik dengan jenis genre yang sesuai dengan kelompok milenial.

\section{Event Carnival}

Dalam kurun waktu 6 tahun terakhir, SMAPKP JIS memiliki kegiatan unggulan yang diberi nama Carnival. Event tahunan yang dirancang dengan tujuan untuk memberi ruang pada kreativitas siswa, mengenalkan sekolah, dan dalam rangka organization branding. Kegiatan carnival diselenggarakan dengan memadukan kegiatan kompetisi bidang olahraga, seni dan budaya literasi. Pedekatan program ini mampu memadukan 3 unsur penting dalam kreativitas siswa yaitu, kompetisi, performance dan culture (budaya). Event tersebut diadakan agar SMA PKP memiliki branding yang kuat dikalangan masyarakat, khususnya para orang tua siswa. Ide branding merupakan proses membentuk dan memasarkan identitas sosial atau lingkungan untuk membedakan sebuah perusahaan meningkatkan citra merk secara keseluruhan (Wirania Swasty, 2016, 26)

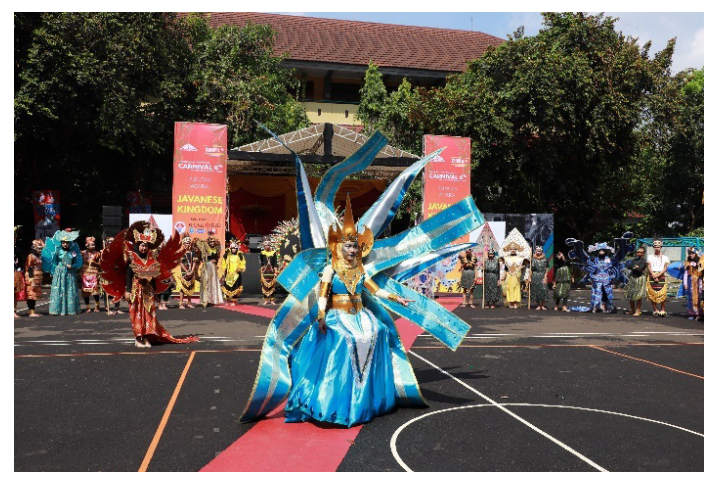

GAMBAR 1. PKP Fashion Canival hasil karya para pelajar SMA PKP JIS)

Nilai dan pengalaman dapat berpengaruh pada kepuasan dan kepercayaan konsumen. Kepercayaan akan berdampak positifpada pembentukan komitmen.

Beberapa event yang diadakan SMA PKP khususnya event carnival telah menarik para pelajar tingkat SMP/ Mts untuk memilih SMA PKP sebagai sekolah lanjutannya. Salah satu faktor 
yang membuat mereka memutuskan masuk ke SMA PKP karena menganggap kegiatan di PKP lengkap, beragam dan berprestasi. Secara keseluruhan kegiatan tersebut dapat meningkatkan nilai (Value Added).

Sebuah studi di Finlandia menemukan sebuah model pembelajaran yang diinspirasi dari praktek kegiatan event di sekolah. Hasil refleksi dan evaluasi terhadap pengalaman mereka mengelola event, menjadi model pembelajaran bahwa memberi kesempatan para pelajar terlibat dalam kegiatan tersebut berarti telah menerapkan teori dan pengalaman lapangan. Hasil akhir mempraktikkan kegiatan event tersebut menunjukkan kemampuan para murid dalam aktivitas pembelajaran. Mereka kemudian mewujudkan gagasan barunya yang diperoleh untuk menjadi bukti adanya portofolio pada saat festival (Slaughter, 2013).

Berbagai lembaga pendidikan di Finlandia menilai bahwa event melatih proses belajar negoisasi antara sekolah dan pemerintah. Kegiatan ini sekaligus memberikan peluang dan pilihan untuk memeroleh sumber pendanaan baik dari pemerintah dan para orang tua/komite sekolah.

Di Finlandia event sekolah dikategorikan kegiatan umum dalam menghadirkan turisme, penyediaan catering dan informasi pengelolaan sekolah. Disana kegiatan di dukung sebagai bagian dari kerjasama perbaikan kurikulum sekolah.

Dalam perspektif pendidikan kegiatan event menambah kepercayaan agar dapat mengimplementasikan konsep-konsep event berskala nasional dan internasional. Informasi ini sekaligus menambah catatan sejarah tentang sarana pengembangan riset, sehingga kegiatan ini sekaligus memberi peluang adanya kesempatan untuk menjadi tempat riset tentang event manajemen di sekolah.

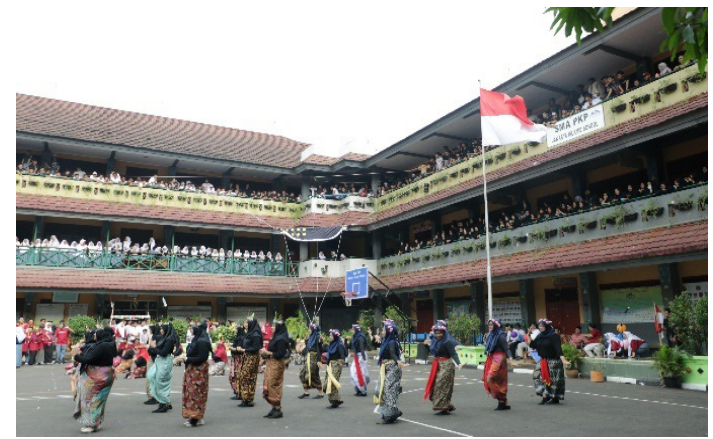

GAMBAR 2. 50 Penari dari pelajar SMA PKP JIS memeriahkan pembukaan Carnival)

Tentang konsep event yang cocok dan menarik buat lembaga pendidikan seperti sekolah, penulis mewawancarai mahasiswa tingkat akhir konsentrasi event Universitas Prasetiya Mulya Sylvia Boneta (2018). Menurut Sibo panggilan pendeknya tentang event yang menarik adalah event yang memenuhi persyaratan sebagai berikut. (1) Event yang ada mampu memberikan impact tak hanya bagi penyelenggara, tetapi berdampak pula kepada pengunjung dan masyarakat sekitar. (2) Event mampu untuk mengeksplorasi kearifan lokal yang ada, bahkan mampu menggerakkan roda perekonomian sekitar dengan memanfaatkan hal tersebut. (3) Memiliki value yang kuat, sehingga identitas yang ada pada sebuah event mampu menjadi ciri khas dan differensiasi dari event lainnya. (4)Mampu memanfaatkan Sumber Daya Manusia (SDM) yang diverse. (5) Memiliki angka toleransi yang tinggi terhadap keseluruhan stakeholder yang ada.

Pertanyaan kedua tentang model event yang cocok untuk anak milenial dan kaitannya dengan promosi sekolah. Sylvia Boneta menjawab:

"Pada dasarnya event itu terbagi menjadi dua. Ada Special Event dan ada MICE. Special event terbagi lagi menjadi empat bagian. Ada Personal Event, Organisational Event, Sport Event dan Cultural Event. Sedangkan MICE di dalamnya mencangkup 
Yayat Wahyat Herianto, dkk. Event Carnival sebagai Media Komunikasi Pemasaran...

Meeting, Incentive, Conference and Exhibition. Adapun menurut saya saat ini banyak event-event yang kaitannya erat dengan milenial mengangkat sebuah event dengan cakupan Cultural Event. Mengapa? Karena saat ini kepedulian anak muda akan budayanya sangat dituntut, agar kebudayaan yang ada tidak punah begitu saja. Tetapi, dengan kreativitasnya, event budaya dikemas secara menarik agar nilai budaya nya tetap ada, tetapi kemasan luarnya lebih milenial. Begitu pula dengan promosi sekolah. Jika konten yang ada erat kaitannya dengan budaya, maka bungkusnya (konteks) harus lebih milenial, agar anak muda tertarik."

Dan pertanyaan ketiga tentang konsep event yang lebih baik di SMA PKP ke depan. Sylvia Boneta menjawab:

"Event berupa pentas seni yang kental dengan kearifan lokal serta experience bagi pengunjung ketika datang ke sebuah event. Karena selama saya belajar di Event Management Universitas Prasetiya Mulya, satu hal yang saya sadari bahwa experience adalah hal yang harus diutamakan agar pengunjung memiliki kesan yang mendalam kepada event yang dilaksanakan. Misalnya membuat pensi dengan konsep "Kisah Para Nabi”, nah nantinya segala ornament dekorasi, bahkan sentuhan di konsep acara akan berpatokan pada konsep tersebut. Bahkan harus jelas pula value yang diangkat apa"

\section{Komunikasi Pemasaran}

Melalui sejarah penelitian komunikasi, Syam (2013) melakukan analisis dan sintesis dengan merekonstruksi (membangun kembali) ilmu komunikasi melalui perspektif pohon. Dengan pendekatan pohon ilmu komunikasi yang diawali dengan akar ilmu menjadi landasan ilmiah bagi pengembangan ilmu komunikasi.

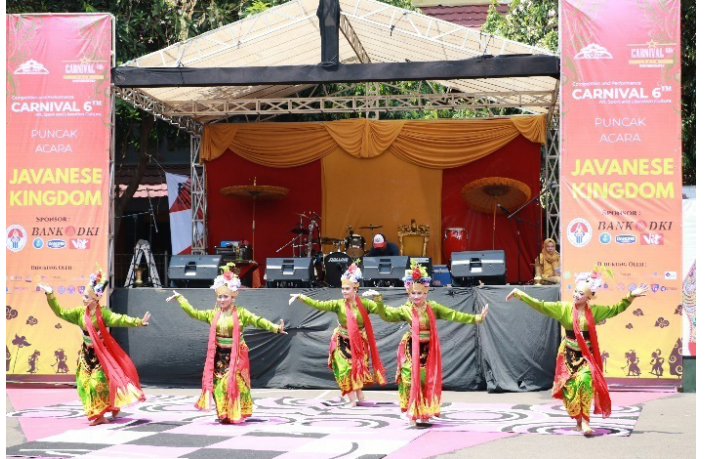

GAMBAR 3. Penampilan tari tradional dari pemenang lomba, panggung berlatar belakang kerajaan jawa

Teori komunikasi yang kini banyak dipelajari dalam kajian ilmu komunikasi berasal dari Yunani Kuno. Plato dan Aristoteles adalah dua tokoh sentral bagi perkembangan ilmu komunikasi (Suciati, 2017). Plato dalam tulisan-tulisannya menunjukan ketertarikan pada studi retorika. Karena itu Plato sangat concern pada pembahasan tentang sifat dari katakata, sifat dari manusia, sifat tentang aturan dan strategi mempengaruhi manusia (Suciati, 2017).

Sebagai sebuah teori ilmu komunikasi memenuhi kaedah-kaedah keilmuan yang sesuai dengan akar dari semua ilmu yaitu filsafat. Tiga pilar filsafat yang dilambangkan sesuai dengan konteks komunikasi yaitu aspek ontologi yang merupakan teori hakikat. Membicarakan apa pengetahuan itu sendiri. Hakikat diartikan sebagai realitas artinya kenyataan yang sebenarnya. Epistimologi merupakan teori dan metode tentang bagaimana cara memperoleh pengetahuan, dasar pengetahuan, asal mula pengetahuan, metode atau cara memperoleh pengetahuan, validitas dan kebenaran pengetahuan. Aksiologi mempelajari tentang manfaat atau nilai apa yang diperoleh dari ilmu pengetahuan. Pilar ini menyelidiki hakikat nilai dari sebuah ilmu pengetahuan. 
Melaksanakan komunikasi dengan sasaran konsumen yang unik dan memiliki ragam kebutuhan yang berbeda, membutuhkan strategi komunikasi tersendiri. Pendekatan ini memusatkan pada penyelidikan terhadap cara manusia memaknai kehidupan sosialnya, serta bagaimana manusia mengekspresikan pemahaman mereka melalui Bahasa, suara, perumpamaan, gaya pribadi, maupun ritual sosial (Deakon, 1999). Dalam bidang komunikasi terdapat paradigma interpretif yang banyak diterapkan pada komunikasi interpersonal, bahasa, interaksi sosial, komunikasi kelompok, komunikasi organisasi, komunikasi lintas budaya, media dan cultural studies, performance studies, komunikasi terapan, dan komunikasi kesehatan (Lindlof dan Taylor, 2002).

\section{Komunikasi}

pemasaran

merupakan pendekatan multidisiplin yang mengabungkan teori dan konsep ilmu komunikasi dan ilmu pemasaran (priansa, 2017). American association of advertising agency, memberi pengertian komunikasi pemasaran sebagai sebuah proses perencanaan komunikasi yang mengetahui nilai tambah dari perencanaan komprehensif komunikasi (Agus, 2012). (Rahma, 2017) memberi pengertian komunikasi pemasaran sebagai suatu penetapan dari tujuan promosi dengan cara membuat rancangan pemasaran.

\section{Event dan Pembentukan Identitas}

Event bagi suatu sekolah bisa dimaknai juga sebagai suatu kesadaran pentingnya mengenalkan identitas kultural kedalam ruang-ruang publik. Kreatifitas yang selama ini dinikmati oleh sebagian besar warga sekolah yang bersangkutan, akhirnya dinikmati juga oleh masyarakat terbuka yang sesungguhnya juga memiliki kesamaan identitas sebagai pelajar. Adanya event ruang-ruang privat kemudian bergeser menjadi ruang-ruang publik.

Secara sosial, proses tersebut bisa diidentikan dengan terbentuknya masyarakat jaringan (Jannah, 2012). (Castells M, 1997) mendefinisikan masyarakat jaringan sebagai masyarakat dengan fungsi dan proses dominan yang dibentuk oleh jaringan, baik intarnet, internet, jaringan kerjasama berbagi perusahaan, organisasi, negara, hingga jaringan pergaulan. Dalam logika jaringan (Raudhatul Jannah, 2012). Kegiatan event carnival juga bisa menjadi sarana pembentukan jaringan-jaringan. Dalam event lomba antar sekolah, peran dominan terlihat pada para pelatih yang sesungguhnya mereka ada dalam jaringan yang sama. Begitu juga dalam menetapkan seni budaya lokal, adaptasi dari seni daerah juga sangat dominan.

Keikut sertaan sekolah luar pada ajang carnival juga tidak terlepas adanya kesamaan kultural masyarakat pendidikan yang sedang mencari bentuk dalam mengenalkan identitasnya kepada khalayak. Dalam hal ini sekolah bisa menggunakan dengan memanfaatkannya. Segi bentuk promosi dengan cara meningkatkan value added (nilai tambah). Karena itulah setiap sekolah membangun brand equitynya juga melalui event internal.

Dalam wawancara dengan ketua OSIS SMA PKP JIS tahun ajaran 2018/2019, M. Ariq Yudhistira menjelaskan bahwa penamaan event di beberapa sekolah unggulan juga sebagai bentuk kebanggaan sekolah yang diwariskan dari generasi pada setiap angkatannya. Ariq menyebutkan beberapa sekolah unggulan dengan nama brand eventnya (TABEL 1).

\section{Aktualisasi Pelajar Milenial}

Identitas brand event untuk pada setiap sekolah khususnya tingkatan SMA, menandai perubahan pakem kebahasaan 
Yayat Wahyat Herianto, dkk. Event Carnival sebagai Media Komunikasi Pemasaran...

TABEL 1. Daftar Sekolah dengan Nama Brand Event Unggulan

\begin{tabular}{lll}
\hline \multicolumn{1}{c}{ NAMA SEKOLAH } & NAMA BRAND EVENT & \multicolumn{1}{c}{ LOKASI } \\
\hline SMA PKP & CARNIVAL & Jakarta Timur \\
SMA Global Islamic & GLOICFEST & Jakarta Timur \\
SMAN 105 & OVERLY & Jakarta Timur \\
SMAN 14 & FOURXTER & Jakarta Timur \\
SMA PB Soedirman & SOEFEST & Jakarta Timur \\
SMAN 99 & EXPERIENCE & Jakarta Timur \\
Labshcool Cibubur & CRAVIER & Cibubur \\
Labschool Rawamangun & LABSPROJECT & Jakarta Timur \\
SMAN 3 & ANTIK & Jakarta Pusat \\
PONPES Al Hamidiyah & AHAFEST & Depok \\
SMAN 48 & FREEDOM & Jakarta Timur \\
SMAN 5 DEPOK & HYPERDUTTY & Depok \\
SMAN 28 & THALLASIC & Jakarta Selatan \\
SMAN 51 & INPARTS & Jakarta Timur \\
SMA School Of Human & SOHFEST & Cibubur \\
SMAN 39 & GADO-GADO & Jakarta Timur \\
SMAN 31 & TOFEST & Jakarta Timur \\
Labschool Kebayoran & SKY AVENUE & Jakarta Selatan \\
SMAN 8 Bekasi & ASTRO & Bekasi \\
SMAN Don Bosco 2 & ARCOFEST & Jakarta Selatan \\
SMAN 70 & SETARA & Jakarta Selatan \\
MAN 2 & ATHLAS & Jakarta Timur \\
SMAN 8 DEPOK & FAS CANOESVEL & Depok \\
SMAN 6 Jakarta & ENTIPRO & Jakarta Selatan \\
\hline
\end{tabular}

(penamaan) dari formal ke informal. Kecenderungan kelompok milenial yang tidak terikat pakem dan cenderung berperilaku "abstrak" terlihat dari pencarian identitas nama-nama brand. Mereka memiliki "credo" bahwa sesuatu yang berbeda merupakan sesuatu yang memiliki daya Tarik. Anak-anak SMA PKP yang datang dari kelompok kelas menengah islam perkotaan, cenderung menampilkan kreativitas unggulan yang selalu diperbaharui. Jaringan komunikasi antar mereka membuat konsep-konsep luar kemudian diadopsi oleh anak-anak SMA PKP.

Dengan demikian, menginterpestasi kegiatan event bagi kelompok milenial sejalandenganhipotesis Castells(Raudatul Jannah, 2012) yang menyatakan bahwa siapapun yang mengonsistruksi identitas dan untuk tujuan apapun, seringkali ditentukan oleh makna simbolik yang ada pada identitas tersebut. Makna simbolik dan identitas yang sedang penelit kaji lebih dalam adalah mengenai promosi.

Secara geografis, SMA PKP berada diwilayah Timur DKI Jakarta sebagai daerah yang berada dipinggiran yang secara sosiologi, warganya dihuni oleh penduduk asli Betawi dan Pendatang/ perantau. Akan tetapi posisi geografis yang bersentuhan dengan daerah 
penyangga baru seperti Depok, Bekasi dan Bogor membuat interaksi mereka masih bergaya urban, masyarakat desa yang sedang mencari identitas sebagai warga kota/metropolis.

\section{Mobilisasi Massa}

Salah satu aspek untuk mengukur suksesnya kegiatan event adalah kehadiran massa/pengunjung. Massa yang banyak menjadi salah satu indikator suksesnya kegiatan event, meskipun kita perlu melihat dari sudut segmentasi pasarnya agar sasaran dan tujuan dapat tercapai.

Dalam konteks event Carnival $\sigma^{\text {th }} 2018$, para pengunjung yang datang dapat diklasifikasikan sebagai berikut: (1) Peseta lomba kegiatan yang terdiri dari lomba futsal, lomba basket, lomba popsong, lomba pidato, lomba LPBB, lomba Ratoeh Jaroe, dan lomba tari tradisional. (2) Pembimbing yang berasal dari guru sekolah asal dan para pelatih lomba. (3) Supporter - supporter lomba adalah mereka yang datang karena memiliki keterkaitan batin dengan para peserta. (4) Pihak sponsor. Mereka yang memberikan bantuan dan sumbangan dana/produk untuk acara tersebut. (5) Undangan, adalah mereka yang dianggap kehadirannya dapat memberikan kualitas/ bobot acara.

Staf humas SMA PKP Andriyani Erna mengestimasi peserta yang hadir dari rangkaian kegiatan. Salah satu sumber penentuan jumlah adalah tiket masuk peserta dan supporter

Jumlah massa yang hadir dalam kegiatan event Carnival :

Bagi Veronica mengambil apa yang ada di masyarakat merupakan sebuah pengalaman yang dapat meningkatkan value added (nilai tambah). Beberapa tindakan positif yang harus dilakukan antara lain melakukan hubungan individual dengan lingkungan sosial, menampilkan pesan-pesan simbolik, menambah tampilan-tampilan sebagai bentuk komunikasi visual, dan kolaborasi dalam menyelesaikan sebuah agenda bersama.

Veronica (2012) menyarankan agar lembaga pendidikan menerapkan konsep IMC (Integrated Marketing Communication). Hal-hal yang harus dilakukan antara lain, melakukan pemilihan konsep dengan menciptakan pernyataan yang luas dengan kualitas pesan yang mendunia. Kata-kata dalam pesan harus bernilai dimata perusahaan asing yang memiliki merk kelas dunia. IMC merupakan proses yang fundamental yang harus menjadi modal organisasi. IMC

TABEL 2. Daftar Klasifikasi Lomba

\begin{tabular}{llll}
\hline Nama Lomba/Event & $\begin{array}{l}\text { Jumlah Peserta Lomba } \\
\text { dan Cadangan }\end{array}$ & $\begin{array}{l}\text { Supporter } \\
\text { /Pendamping } \\
\text { /Undangan }\end{array}$ & Jumlah \\
\hline Futsal & 400 & 800 & 1.200 \\
Basket & 396 & 660 & 1.056 \\
LPBB & 105 & 200 & 305 \\
Pidato Agama Islam & 23 & 115 & 138 \\
Pop Song & 26 & 130 & 156 \\
Tari Saman & 105 & 140 & 162 \\
Tari Tradisional & 42 & 120 & 162 \\
Acara Puncak & & & 800 \\
Jumlah & & & 4.062 \\
\hline
\end{tabular}


Yayat Wahyat Herianto, dkk. Event Carnival sebagai Media Komunikasi Pemasaran...

juga harus mengakomodir pendekatan non marketing seperti kesehatan, sosial marketing dan lain-lain.

\section{SIMPULAN}

Event merupakan jenis dan bentuk kegiatan yang menarik dan penting, sebagai bentuk transformasi ekonomi dan kultural tentang pentingnya memperingati dan merayakan sesuatu. Event carnival menjadi model komunikasi pemasaran yang efektif untuk bisa meningkatkan brand sekolah, membangun identitas jaringan, mengembangkan budaya dan mengenalkan kearifan lokal serta menjadi bagian promosi sekolah yang sangat efektif.

\section{DAFTAR PUSTAKA}

Brown, S., \& James, J. (2011). Event design and management: ritual sacrifice? In Festival and Events Management. https://doi.org/10.1016/B978-0-75065872-0.50009-0

Bungin, M Burhan. (2017). Penelitian Kualitatif, Penerbit Kencana

Castells M. (1997). Castells- the power of identity Book review. Society.

Cerulo, K. A. (1997). Ueber den diagnostischen Wert und die kortikale Lokalisation des Oppenheimschen Reflexes. Identity Contruction, 53(48), 2022-2023. https://doi. org/10.1055/s-0028-1127025

Crowther, P. (2011). Marketing event outcomes: From tactical to strategic. International Journal of Event and Festival Management, 2(1), 68-82. https://doi. org $/ 10.1108 / 17582951111116623$

Getz, D., Andersson, T., \& Carlsen, J. (2010). Festival management studies: Developing a framework and priorities for comparative and cross-cultural research.International Journal of Event and Festival Management. https://doi. org/10.1108/17852951011029298

Hermawan, Agus, 2012, Komunikasi Pemasaran, Penerbit Erlangga

Iriantara, Yosal. (2017). Komunikasi Kepemimpinan Pendidikan, Penerbit
Simbiosa Rekatama Media

Jannah, R. (2012). Jember Fashion Carnival: Konstruksi Identitas dalam Masyarakat Jaringan $\mathrm{R}$ a u d 1 a t u $1 \mathrm{~J}$ a $\mathrm{n} \mathrm{n}$ a h. Jember Fashion Carnival. Retrieved from www.jemberfahsioncarnival.com

Juni, Doni Priansa. (2017). Komunikasi Pemasaran Terpadu, Penerbit Pustaka Setia Warta Waska, 2012, Manajemen Reputasi, Penerbit Simbiosa Rekatama Media

Kose, H., Argan, M., \& Argan, M. (2011). Special Event Management and Event Marketing: A case study of TKBL all star 2011 in Turkey. Journal of Management and Marketing Research, 8(1), 1-11.

Noor, Any. (2017). Manajemen Event, Penerbit Alfabeta

Pan, B., Pan, B., \& Huan, T. C. (2013). New perspectives on festival and events research. International Journal of Culture, Tourism and Hospitality Research, 7(2), 115-117. https://doi. org/10.1108/IJCTHR-04-2013-0018

Rahma, A. (2017). Event Sebagai Salah Satu Bentuk Strategi Komunikasi Pemasaran Produk Fashion Nasional (Event Tahunan Jakcloth). Journal of Communication (Nyimak), l(Juni), 9.

Slaughter, L. (2013). No Title. Event Management Eduation in Finland.

Suciati. (2017). Teori Komunikasi dalam multi perspektif, Penerbit Buku Litera Yogyakarta

Swasty, Wirania. (2016). Branding, Penerbit PT Remaja Rosdakarya

Syam, Nina W. (2013). Model-model Komunikasi : Perspektif Pohon Komunikasi, Penerbit Simbiosa Rekatama Media

Wu, S.-I. (2016). Competing Model of Event Marketing Activities. International Journal of Marketing Studies, 8(4), 52. https://doi.org/10.5539/ijms.v8n4p52

Yusuf, Amri. (2018). Budaya Korporasi : Elemen Fundameltal Transformasi Korporasi, Penerbit Buku Kompas

Wawancara:

1. Ariq Yudistira, Ketua OSIS SMA PKP JIS Tahun Ajaran 2018/2019

2. Silvia Boneta (Sibo) .Mahasiswa 
MediaTor, Vol 12 (1), Juni 2019, 15-26

Prodi Event Management Universitas

Prasetiya Mulya 